\title{
Perancangan produk fungsional berbahan limbah kayu sisa produksi tempat air kemasan gelas
}

\author{
Achmad Zainudin, ${ }^{1 *}$ Dwi Agus Susila, ${ }^{2}$ \\ ${ }^{1,2}$ Program Studi Desain Produk, Universitas Islam Nahdlatul Ulama, Jepara, Indonesia
}

\begin{abstract}
The initial idea of this research is to exploit the abundance of wood waste material in the form of coins which have almost the same size and thickness. This waste comes from the rest of the production of glass bottled water. One way to achieve this goal is by using horizontal and vertical lamination techniques with the addition of a turning process with the aim of being able to form and produce functions. Another goal is to apply the waste coin arrangement as a functional and decorative product design material. The design of this product with waste is used as a model for empowering the creative industry of the local crafts-producing community where glass mineral water is located in Sambeng Village, Kasiman District, Bojonegoro Regency, East Java. The design method used is the Design Thinking method. The output produced is in the form of functional and decorative product designs, such as stools, wall clocks, frames, candle holders, egg holders, menu boards, and placemats.
\end{abstract}

Key words: wood waste, design thinking, craft products

\begin{abstract}
Abstrak
Ide awal penelitian ini adalah upaya pemanfaatan melimpahnya bahan limbah kayu berbentuk koin yang memiliki ukuran dan tebal hampir sama. Limbah ini berasal dari sisa produksi tempat air kemasan gelas. Untuk mencapai sasaran tersebut salah satu caranya yaitu dengan teknik laminasi secara horisontal dan vertikal dengan penambahan proses pembubutan dengan tujuan dapat membentuk dan melahirkan fungsi. Tujuan lainnya adalah mengaplikasikan susunan limbah koin sebagai bahan perancangan produk fungsional dan dekoratif. Perancangan produk dengan limbah ini dijadikan model untuk pemberdayaan industri kreatif masyarakat daerah penghasil kerajinan tempat air mineral gelas yang berlokasi di Desa Sambeng Kecamatan Kasiman Kabupaten Bojonegoro Jawa Timur. Metode perancangan yang digunakan adalah metode Design Thinking. Output yang dihasilkan adalah berupa desain produk yang fungsional dan dekoratif, seperti stool, jam dinding, pigura, tempat lilin, tempat telur, papan menu, dan tatakan.
\end{abstract}

Kata kunci: limbah kayu; design thinking; produk kerajinan

\section{Pendahuluan}

Munculnya perancangan desain re-use limbah (kayu lingkaran) ini berawal dari keprihatinan penulis melihat melimpahnya limbah yang dihasilkan dari proses produksi kerajinan tempat air minum gelas yang ada di desa Sambeng Kasiman Bojonegoro (Gambar 1). Di sisi lain mereka juga mengeluhkan sulitnya mendapatkan pasokan kayu limbah untuk pembuatan souvenir wadah air minum kemasan, demikian hasil perbincangan penulis dengan Muntari sebagai Ketua KUB Karya Bakti. Selain itu terdapat juga limbah berupa koin yang mempunyai bentuk, ukuran dan ketebalan yang hampir sama yaitu diameter $50 \mathrm{~mm}$, ketebalan 15-20 mm dari kayu jati dihasilkan oleh hampir 25 pengrajin di desa Sambeng yang tergabung dalam kelompok usaha bersama KUB "Karya Jati" yang diketuai oleh Muntari. Ide pemanfaatan limbah tersebut ternyata sesuai pemikiran penulis baik secara karakter fisik maupun performa akhir yang bisa termanfaatkan dan berdampak multifungsi khususnya pemecahan masalah bagi pengrajin. Beberapa temuan yang dihasilkan dari observasi langsung dan studi pustaka dapat dimunculkan sebuah desain yang bisa menstimulus performa fisik (fungsi, bentuk, strukstur,

\footnotetext{
* Corresponding author e-mail : dzain@unisnu.ac.id
} 
dan nilai estetis) dalam rangka untuk membangun pola pikir pengrajin yang memanfaatkan limbah kayu yang tersedia.

Penulis juga berkeyakinan bahwa pengrajin yang tergabung dalam usaha bersama tersebut akan mampu berpikir kreatif dan tergerak untuk berinovasi secara berkelanjutan dalam melahirkan rancangan baru yang siap diproduksi. Barati, Karana, dan Hekkert (2019) mengatakan,

"materials are far from being integrated in products due to being underdeveloped, i.e., certain aspects of them, including their structure, fabrication, properties, and behavior, are either unknown or undefined, thus, understanding them and exploring their potentials and boundaries can be a challenge for designers."

Bentuk atau struktur karya mengacu pada karakter bahan yang relatif sama ukurannya merujuk pada produk fungsional dan dekoratif yang secara visual mampu memperlihatkan karakter bahan dengan sentuhan lokal sebagai penguat nilai estetis. Tampilan karya dengan konsep tersebut sebagai pemecahan masalah kelesuan produksi pengrajin yaitu inovasi melalui karya pemanfaatan limbah kayu. Beberapa upaya pemanfaatan limbah kayu menjadi produk yang memiliki value tinggi telah banyak dilakukan dalam penelitian sebelumnya (Beatrice et al., 2018; Naimah et al., 2029; Suprapto et al, 2021; Sutanto \& Tedjokoesoemo, 2017), termasuk limbah kayu industri mebel (Eskak, 2000; Prasetya, 2015).

Produk yang inovatif tersebut sejalan dengan Undang-Undang Industri Hijau oleh Kementerian Perindustrian Republik Indonesia berdasarkan Undang-Undang Republik Indonesia No. 3 tahun 2014 tentang Perindustrian, yakni industri yang dalam

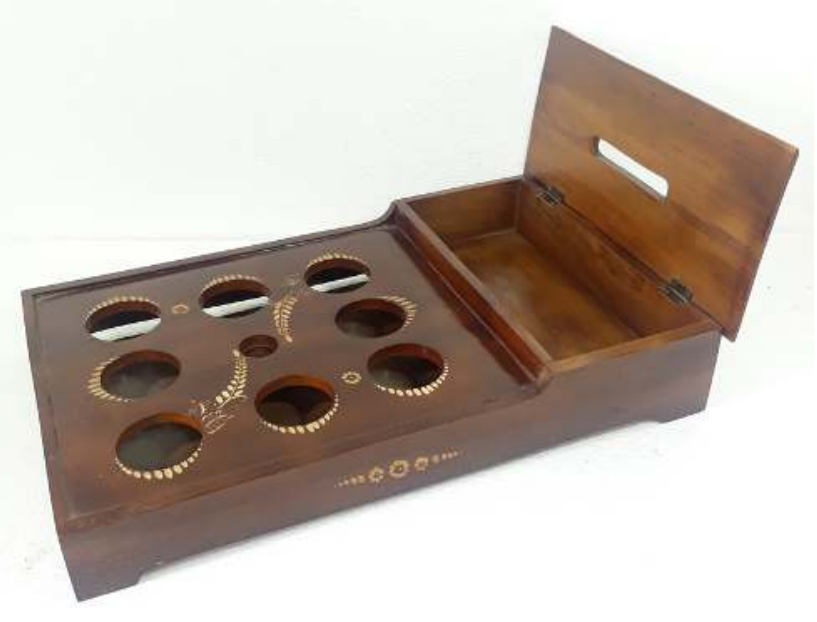

Gambar 1. Produk tempat air kemasan gelas (sumber: http://hiasankayu.com) proses produksinya mengutamakan upaya efisiensi dan efektivitas penggunaan sumber daya secara berkelanjutan sehingga mampu menyelaraskan pembangunan industri dengan kelestarian fungsi lingkungan hidup serta dapat memberi manfaat bagi masyarakat (Pemerintah Republik Indonesia, 2014). Berdasarkan pengamatan dan observasi yang dilakukan penulis, di wilayah ini belum terdapat eksperimen yang pernah ada terutama untuk mengetahui susunan secara vertikal, horisontal, bentuk serta fungsi yang maksimal dari limbah koin tersebut. Untuk lebih mengangkat mutu dan kuantitas hasil penelitian, penulis mengangkat karya ilmiah yang telah ada yaitu bagaimana produk dihasilkan dengan teknik laminasi yang dapat menyatukan potongan-potongan kecil kayu saling menempel membentuk objek benda atau bidang dengan perekat lem yang kuat (Eskak, 2000). Pada saat ini limbah kayu berbentuk koin biasanya hanya dibuang atau dibakar saja, karena memang mereka belum menemukan satu langkah produksi yang lebih menguntungkan serta tidak memerlukan pemikiran.

Oleh karena itu limbah ini sangat menarik untuk dikembangkan dengan perancangan produk kekinian dengan mempertimbangkan tingkat ketersediaan bahan baku limbah yang cukup tinggi yaitu sekitar satu karung dihasilkan setiap hari oleh masing-masing pengrajin. Dimana ukuran tiap satu karung berisi sekitar 1000 koin, sehingga dalam hitungan penulis limbah tersebut bisa dihitung menjadi $1000 \times 25$ Pengrajin dengan hasil akhir 25.000 koin /hari.

\section{Metodologi}

Pada tindakan penelitian setiap orang dapat memecahkan masalah dengan langkah yang berbeda, salah satunya dengan cara merancang tindakannya berdasar pada pertimbangan tujuan dan efek yang diinginkan. Ketika menghadapi permasalahan yang ditemukan, maka desainer dianggap memiliki kelebihan dalam mengolah permasalahan itu secara sadar dan intuitif sehingga dapat membentuk solusi yang lebih tertata dan bermakna. Dalam penelitian juga dapat menggunakan metode pemecahan masalah melalui optimalisasi fungsi yang ditampilkan dalam pengolahan bentuk (form); rekayasa tingkat pemahaman (content); dan/atau pertimbangan hubungan (context) antara hasil luaran (output) dan capaian (outcome) dengan penciptaan nilai yang memperhatikan keselamatan, keamanan, kesehatan, kenyamanan, serta keindahan bagi manusia dan lingkungannya. 
Pada penelitian ini digunakan metode eksperimen aplikatif yang akan diterapkan pada perancangan produk menggunakan limbah koin kayu jati dan upaya mendapatkan pemahaman bahan baku yang bentuknya kecil dan bisa dimaksimalkan dengan penggabungan secara vertikal atau horisontal sehingga menjadi struktur atau papan yang kuat dan bisa dipertanggungjawabkan serta mampu membangun produk fungsional dan dekoratif.

Selain kegiatan eksperimen, pengumpulan data dilakukan dengan cara pengamatan langsung, interviu, FGD untuk mendapatkan informasi dan data mengenai aplikasi teknologi material terkait karakter limbah industri kayu, nilai-nilai ramah lingkungan, bahan-bahan pendukung, aplikasi ragam konfigurasi bentuk, standar kemampuan material perancangan produk, proses produksi limbah koin, serta perumusan masalah.

\section{Hasil dan pembahasan}

Pola pikir desain (Design Thinking) merupakan metode berpikir yang secara dinamis mendorong ragam pendekatan dan tindakan yang didasari keinginan untuk menciptakan inovasi sebagai solusi. Pendekatan dan tindakan yang dimaksud dapat berupa campuran berpikir imajinatif dan kritis, divergenkonvergen, dan berlandaskan percobaan-percobaan berbagai kemungkinan (trial-error).

Dalam penelitian ini juga akan dilakukan perancangan produk dengan sistematis, yaitu dimulainya identifikasi yang meliputi buku referensi untuk memunculkan ide dalam bentuk sketsa desain (exploration of idea), melakukan modelling susunan dan bentuk yang sesuai dari material yang tersedia dengan aplikasi Autocad, membuat gambar kerja untuk produksi kerajinan, tahapan assembling atau perakitan komponen dimulai dari bahan yang sesuai kebutuhan hingga sampai finishing akhir dengan cat water-based dengan pertimbangan aplikasinya mudah dan murah untuk dilakukan oleh pengrajin. Gambar 2 memperlihatkan pola pikir yang digunakan dalam penelitian ini, yang terdiri dari tahap Definisi, Teliti, Gagas, Kembang, dan Implementasi (Pasaribu, 2020).

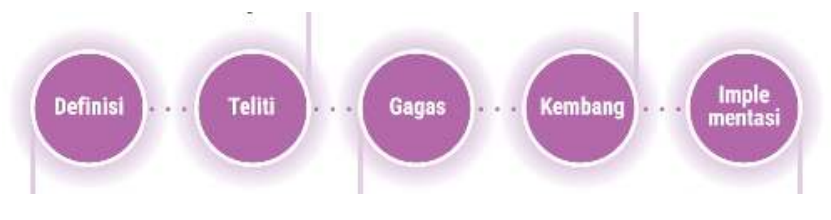

Gambar 2. Design Thinking (Pasaribu, 2020)
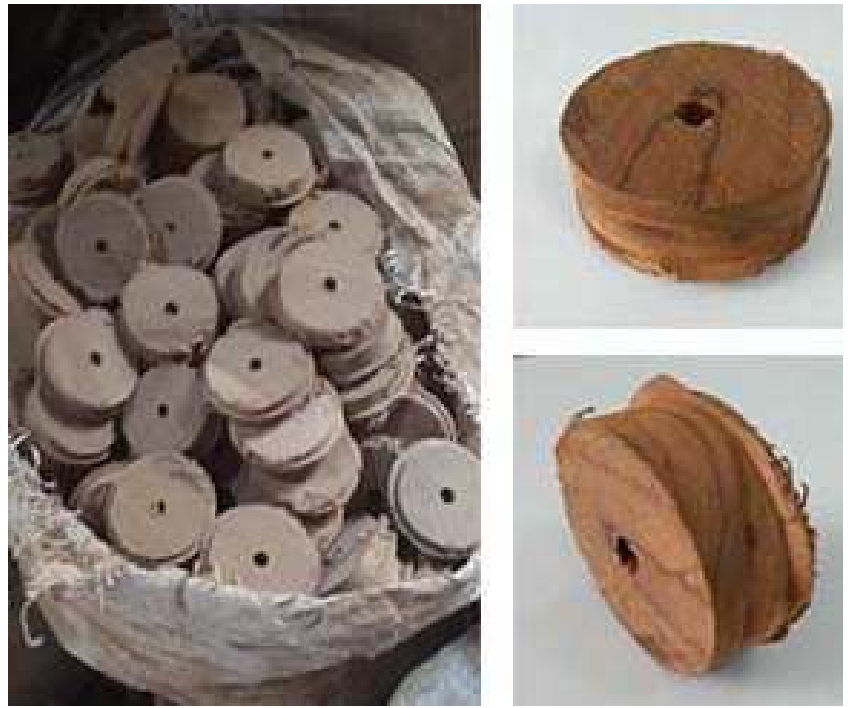

Gambar 3. Limbah koin kayu jati

Tahap Definisi. Kayu sisa potongan adalah bagian kayu yang terdiri dari berbagai bentuk dan ukuran sehingga dalam proses produksinya mengalami hambatan, karena dianggap tidak dapat menghasilkan produk (output) yang bernilai tinggi dari segi ekonomi dengan tingkat teknologi pengolahan tertentu yang kemungkinan dapat digunakan.

Tahapan Teliti. Ada 3 tahapan penelitian yang dilakukan, yaitu (1) Merumuskan pemanfaatan (reuse) limbah kayu yang berfungsi sebagai tempat minum gelas sebagi inovasi pengrajin di Desa Sambeng, Kasiman, Bojonegoro, Jawa Timur dengan mewujudkannya ke dalam karya desain kerajinan dan mebel untuk menstimulus kreativitas dan inovasi pengrajin yang mempunyai nilai kebaruan; (2) Metode interviu dilakukan secara langsung bertatap muka dan diskusi group terbatas (FGD) yang diselenggarakan oleh Dinas Perindustrian Bojonegoro dalam hal ini adalah bapak Suliyana selaku koordinator pelatihan dengan 30 Peserta yang berasal dari dua Desa Sambeng dan Batokan; (3) Wawancara secara mendalam dengan narasumber (Muntari selaku Ketua KUB"Karya jati") di rumahnya yang terletak di desa Sambeng dan secara online melalui aplikasi Whatsapp. Observasi langsung dilakukan ke tempat kerja/workshop 3 narasumber (Muntari, Lugito dan Priyono) yang berlokasi di desa Sambeng dan 1 narasumber (Jamudi) yang berada di desa Batokan.

Dari beberapa tahapan penelitian yang dilakukan di lokasi diperoleh beberapa temuan penting, yaitu: (1) Limbah dari produksi souvenir wadah air minum kemasan hanya dibakar untuk memasak; (2) Terdapatnya limbah berbentuk koin dengan diameter $50 \mathrm{~mm}$ dan ketebalan antara $15-20 \mathrm{~mm}$ dari proses pelubangan yang tidak difungsikan sebagai produk 


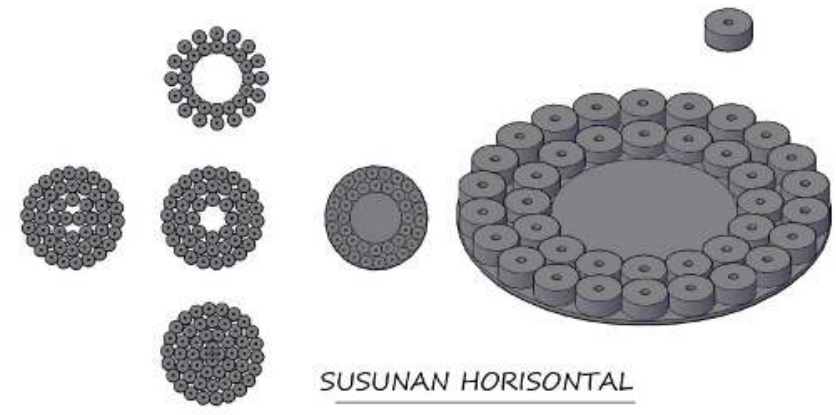

Gambar 4. Susunan koin horisontal

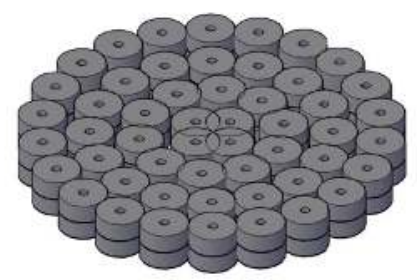

SUSUNAN VERTIKAL

Gambar 5. Susunan Koin Vertikal
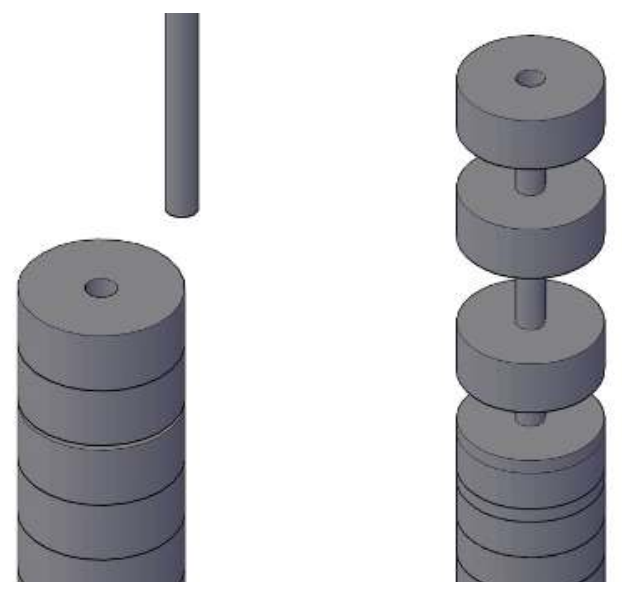

Gambar 6. Susunan sambungan

Tabel 1, Susunan koin dan produk

\begin{tabular}{cll}
\hline No & Susunan dan struktur koin & \multicolumn{1}{c}{ Rancangan produk } \\
\hline 1 & Vertikal & Kaki Stool dan Meja \\
2 & Horizontal & Bentuk Jam, Dudukan, Pigura \\
3 & Vertikal dan Bubut & Tempat Lilin,Tempat Telur \\
\hline
\end{tabular}

(Gambar 3); (3) Adanya keinginan bersama untuk inovasi produk dari limbah yang dihasilkan oleh produksi tempat air minum kemasan, jika ada fasilitas dari pemerintah dalam proses perancangan produk; (4) Kekhawatiran terhadap produk yang sudah diproduksi tidak laku di market pasar; (5) Lokasi kerja menyatu dengan rumah, ada yang di bagian belakang, samping dan depan rumah sehingga mudah untuk mobilisasi; (6) Alat produksi yang dimiliki cukup lengkap untuk pengerjaan skala rumah tangga, yaitu alat-alat untuk pemotongan (sawing), pembentukan sesuai pola (shaping), pelubangan (boring), dan penghalusan (sanding); (7) Pekerjaan dilakukan dengan 1-2 orang dibantu oleh istri dalam proses finishing.

Tahapan Gagas. Desain adalah kegiatan pemecahan masalah dan inovasi teknologis yang bertujuan untuk mencari solusi terbaik dengan jalan memformulasikan terlebih dahulu gagasan inovatif ke dalam suatu model, dan kemudian merealisasikan kenyataan secara kreatif dan inovatif. Gambar 4-6 memperlihatkan susunan yang disarankan untuk perancangan.

Desain bagi sebagian besar pelaku industri furnitur belum dianggap penting, sehingga tidak aneh jika produk industri kerajinan Indonesia, salah satunya adalah Desa Sambeng, Kecamatan Kasiman, Kabupaten Bojonegoro kurang memiliki geliat peningkatan produksi yang berdampak kesejahteraan pengrajin. Bahan baku kayu semakin terbatas karena munculnya berbagai kebijakan pemberantasan illegal logging. Selain itu, saat ini terdapat kebijakan baru bahwa beberapa negara pengimpor hanya mau menerima produk jadi kayu yang bahan bakunya memiliki asal-usul jelas. Hal tersebut memerlukan pemecahan masalah secara nyata melalui kekaryaan desain yang berbasis budaya dan sumber daya lokal yang tersedia. Melalui identifikasi aspek-aspek desain yang berbasis inovasi dan budaya lokal untuk diaplikasikan pada desain furnitur dan kriya. Inovasi melalui re-use atau pemanfaatan kembali material atau barang yang sudah tidak berguna menjadi lebih berguna dan bersifat ramah lingkungan, serta desain yang unik.

Tahapan Implementasi dan Aplikasi. Proses juga diartikan sebagai cara, metode ataupun teknik bagaimana produksi itu dilaksanakan. Produksi adalah kegiatan untuk menciptakan dan menambah kegunaan (utility) suatu barang dan jasa. Menurut Ahyari (2002) proses produksi adalah suatu cara, metode ataupun teknik menambah kegunaan suatu barang dan jasa dengan menggunakan faktor produksi yang ada. 
Achmad Zainudin, Dwi Agus Susila

Perancangan produk fungsional berbahan limbah kayu sisa produksi tempat air kemasan gelas
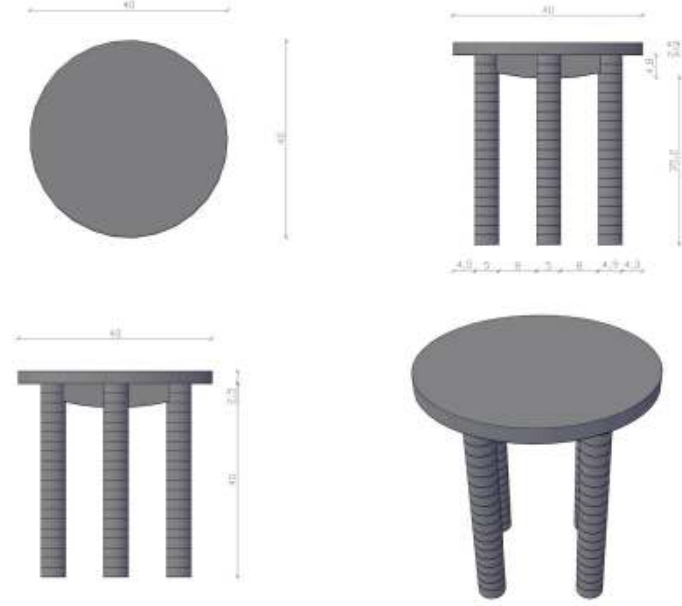

Gambar 7. Desain stool
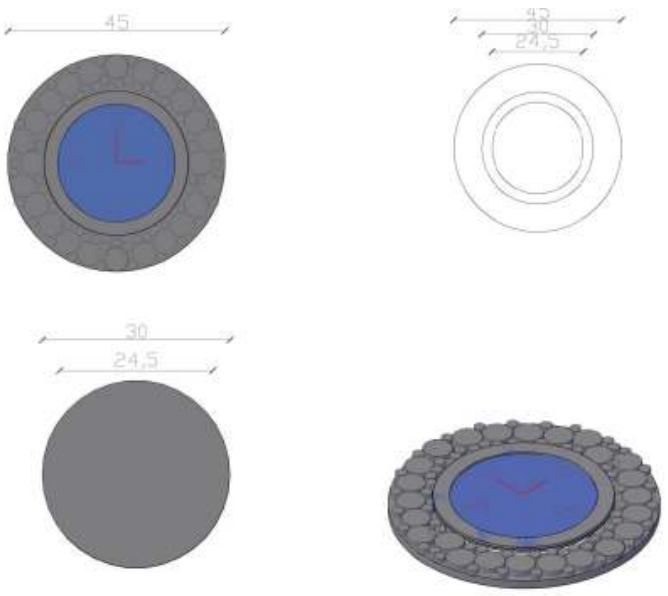

Gambar 8. Desain jam dinding
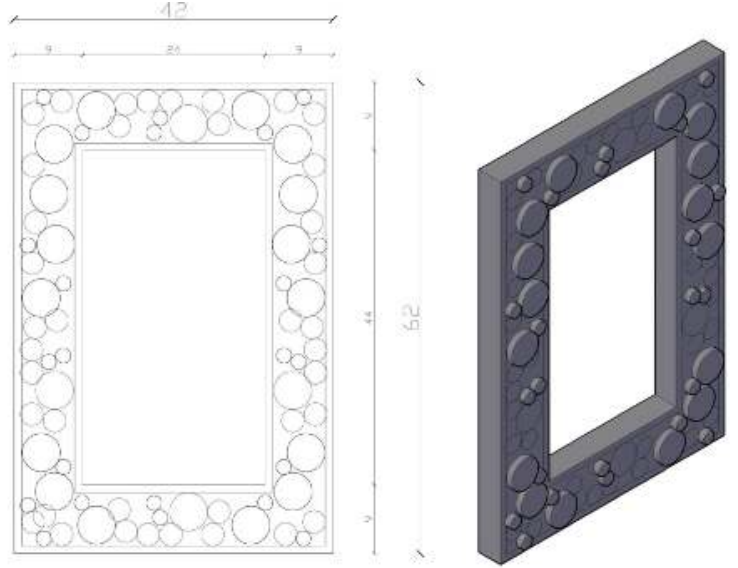

Gambar 9. Desain pigura
Tabel 2. Alat dan bahan

\begin{tabular}{ccl}
\hline No & \multicolumn{1}{c}{ Susunan } & \multicolumn{1}{c}{ Alat dan Bahan } \\
\hline 1 & Vertikal & $\begin{array}{l}\text { Mesin gerinda, palu, limbah } \\
\text { koin, dowel 10mm, lem } \\
\text { aliphatic }\end{array}$ \\
& & $\begin{array}{l}\text { Mesin gerinda, palu, limbah } \\
\text { koin, dowel 10mm, lem } \\
\text { aliphatic, triplek 3mm } \\
\text { Horisontal } \\
\text { Mesin gerinda, palu, limbah } \\
\text { koin, dowel 10mm, lem } \\
\text { aliphatic }\end{array}$ \\
\hline
\end{tabular}

\section{Hasil Pengembangan}

Empat produk yang dihasilkan sebagai output dari penelitian adalah stool, papan menu, pigura, dan jam dinding seperti yang diperlihatkan oleh Gambar 10 dan 11. Produk stool tersebut memiliki spesifikasi sebagai berikut: tinggi $41 \mathrm{~cm}$, diameter kaki $5-3 \mathrm{~cm}$ jenis limbah koin kayu jati, susunan vertikal dengan bantuan mesin bubut, diproduksi secara manual, waktu produksi berkisar 3 jam, dan konstruksinya menggunakan dowel dan lem kayu aliphatic crona.

Sedangkan produk papan menu, pigura, dan jam dinding tersebut memiliki spesifikasi: jenis limbah koin kayu jati, susunan horisontal, produksi manual, menggunakan triplek $3 \mathrm{~mm}$ untuk merangkai susunan yang dibutuhkan, menggunakan campuran serbuk kayu dan lem untuk mengisi jarak antar koin, dan waktu yang dibutuhkan untuk produksi kurang lebih 3 jam, lem kayu yang digunakan jenis aliphatic crona.

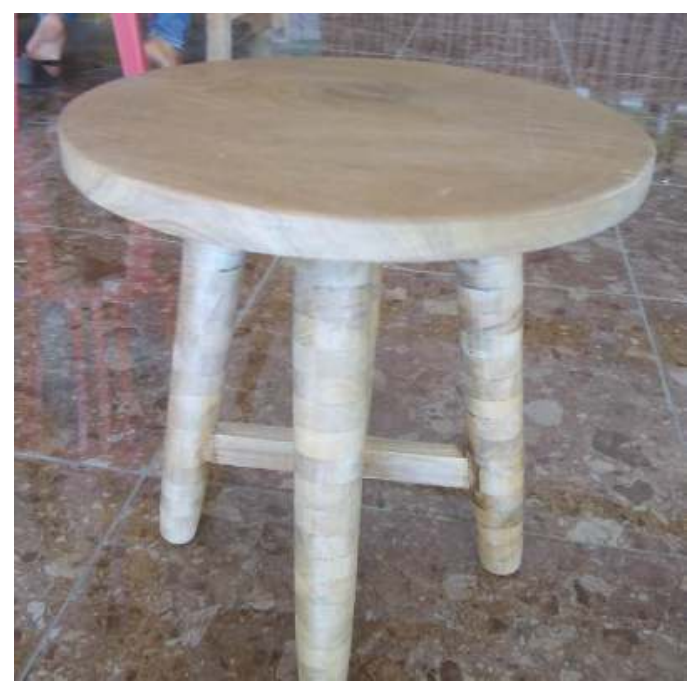



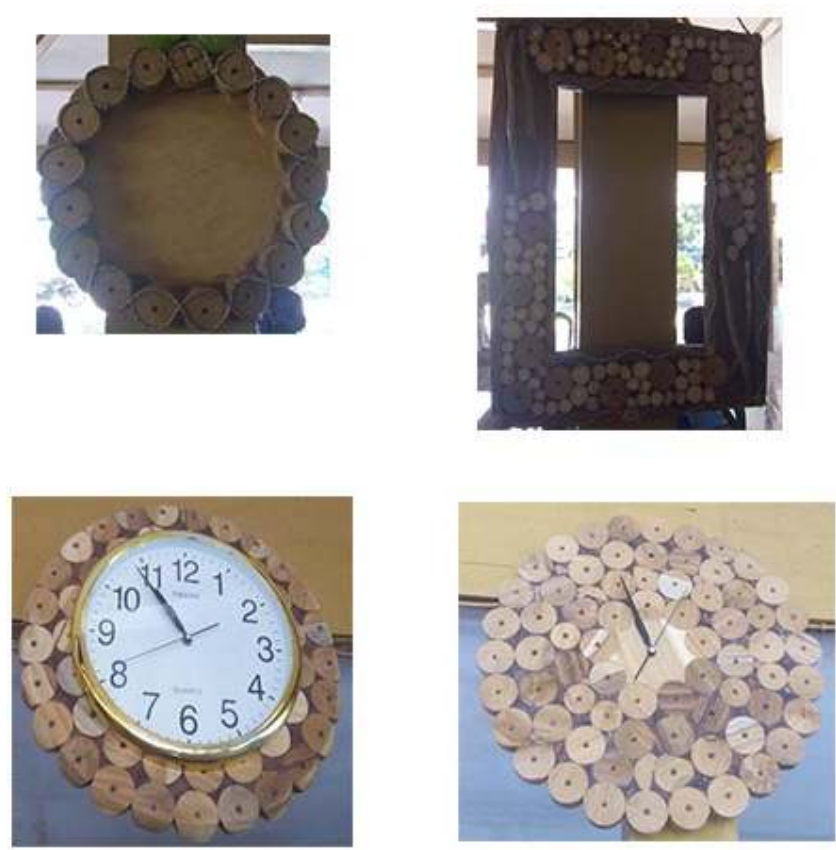

Gambar 10. Koin items

\section{Penutup}

Dari ulasan penelitian dan pembahasan di atas, dapat disimpulkan beberapa variabel yang bermanfaat, antara lain adalah,

1. Limbah koin kayu jati bisa dimanfaatkan sebagai bahan baku pembuatan material dengan struktur konsep desain re-use (pemanfaatan kembali) dengan gaya posmoderen dan bersifat stimulan berpikir lebih ekonomis dan kreatif dalam memanfaatkan limbah kayu yang begitu melimpah.

2. Proses produksi membutuhkan waktu yang singkat dengan menggunakan alat manual yang sesuai kemampuan pengrajin, penggunaan alat-alat produksi yang direkayasa sederhana dalam proses pengerjaan desainnya

3. Implementasi susunan secara vertikal mampu mengembangkan pemanfaatan limbah koin menjadi struktur papan yang kuat dan estetis untuk bahan baku produksi elemen fungsional dan estetis, seperti furnitur, dekoratif dan pendukungnya.

4. Membuka peluang usaha kreatif baru yang mudah dan ekonomis dan membuka lapangan kerja baru bagi masyarakat. Sehingga dimungkinkan peningkatan pendapatan secara bertahap masyarakat pengrajin pada khususnya dan berkembangnya tingkat kesejahteraan masyarakat secara lebih luas.

\section{Daftar pustaka}

Ahyari, A. (2002). Manajemen Produksi dan Pengendalian Produksi. BPFE.

Barati, B., Karana, E., \& Hekkert, P. (2019). Prototyping materials experience: towards a shared understanding of underdeveloped smart material composites. International Journal of Design, 13(2), 21-38.

Beatrice, A. E., Setiadi, S., Saraswati, D. K., \& MT, S. S. (2018). Pemanfaatan Limbah Kayu Peti Kemas Sebagai Bahan Dasar Perancangan Aksesoris Interior Pengembangan Metodologi Penciptaan Seni Rupa dan Desain. Seminar Nasional Seni Dan Desain 2018, 57-63.

Eskak, E. (2000). Pemanfaatan Kayu Limbah Industri Mebel Untuk Penciptaan Karya Seni. Skripsi. S-1 Fakultas Seni Rupa. Yogyakarta: Institut Seni Indonesia.

Naimah, R. J., Hawinuti, R., Firdaus, M., \& Gazalie, R. (2019). Pelatihan Pembuatan Furniture dari Bahan Limbah Kayu Pallet. Jurnal IMPACT: Implementation and Action, 2(1), 2431.

Pasaribu, Y. M. (Ed.). (2020). Proyek Desain. Kementerian Pariwisata dan Ekonomi Kreatif RI-Deputi Bidang Kebijakan Strategis.

Pemerintah Republik Indonesia. (2014). Undang-undang Republik Indonesia Nomor 3 Tahun 2014 tentang Perindustrian.

Prasetya, R. D. (2015). Potensi Limbah Kayu Industri Mebel untuk Produk Home Accessories. Productum: Jurnal Desain Produk (Pengetahuan Dan Perancangan Produk), 1(1), 3951.

Suprapto, V., Kusumarini, Y., \& Tanaya, F. (2021). Perancangan produk interior modular berbahan upcycling kayu bekas palet. Productum: Jurnal Desain Produk (Pengetahuan Dan Perancangan Produk), 4(1), 77-86.

Sutanto, J., \& Tedjokoesoemo, P. E. D. (2017). Upcycle Limbah Kayu Palet Jati Belanda Menjadi Wadah Modular Serbaguna untuk Anak-Anak (Studi Kasus: Kota Surabaya). Dimensi Interior, 15(1), 26-34. 